\title{
ホスピス文献の分析
}

一NLM Literature Search を利用して一

\section{Analysis of References on "Hospices" - by use of NLM Literature Searh-}

\author{
青 木 仕* \\ 順天堂大学図書館
}

Aoki, M. : Analysis of References on "Hospices" - by use of NLM Literature Search.-Igaku Toshokan 32 (4) : 347-357, 1985.

Five hundred and twenty three references on "Hospices" which were referred in NLM Literature Search No. 79 -8 and No. 84-4 were analyzed. These references were published from January 1966 to February 1984.

The following results were obtained :

1) There were 238 serial journals and there was no core journal concerning "hospices"

2) 238 serial journals were published in 17 countries under 523 titles, of which 162 journals $(68.06 \%)$ and 361 titles $(69.03 \%)$ were found in the U. S. A.

3) 238 journals were classified under 32 subjects by the NLM classification, of which the most frequent one was “Medical Science-Nurses and Nursing” (57 journals 23. $94 \%, 147$ titles $28.11 \%$ )

4) The number of journals on "Hospices" has been increased markedly from 1976 to 1979, and thereafter has been increasing gradually.

5) Of the major descriptors, 189 were selected and the most frequent descriptor was "Hospices" which was given to 395 under 523 titles $(75.53 \%)$.

6) Of the number of major descriptors, two were most frequent and given to 205 titles. Of the number of "All" descriptors six were most frequent and given to 95 titles.

7) Of the major descriptors, "Hospices" was more frequent than "Terminal Care" or "Hospitals, Special".

8) Of the subheadings which were given to the major descriptor "Hospices", the most frequent one was "Organization \& Administration" (124 citations).

\section{I 。はじめに}

現代医学は延命に対して目覚しい進歩を遂げたが, 万人は死から免れることはできない。

高齢化社会が進むなかで，老いのために死を迎える 人々や死を前にした末期患者のためにいかにして希望 を与之, 平安の中に死出の旅につかせるかは以前より いっそう切実な問題になりつつある。こうした人々の

* Manabu AOKI : Juntendo University Library 2-26, 2-chome, Bunkyo-ku, Tokyo 113, Japan

(昭和60年11月 5 日 受理)
ために肉体的ケアのみならず，精神的ケア，社会的苦 痛へのケアをも併せて考える必要性がおこって来てい る。近年, 我国でもホスピス・ケアが注目され始めて いる。 ${ }^{1)}$ ホスピスに関してテレビ, 雑誌, 新聞等一般報 道がなされるなかで, 学術文献上ではどのような動向 になっているか興味を持った。このような調査は, 過 去にイギリスにおいて Barbara Greenall が19761981年を対象に詳細な報告をしている。

今回, 医学関係の関心事やトピックス的なテーマに 関しての文献がまとめてある National Library of Medicine Literature Search (以下 NLM Literature 
Search）に2 回にわたって掲載されていた，ホスピス 関連文献523件について, その雑誌の分析とホスピス文 献に付与されていた Descriptor の調査を試みたので ここに報告する。

\section{II. ホスピスについて}

ホスピス (Hospices) とはラテン語の hospitium が 語源であり, 歓待, 宿所, 宿屋の意味である。「オック スフォード辞典」によれば, 巡礼者, 旅行者, 他国者, 貧困者，病人たちを休ませ，歓待する家と説明してい る。中世のヨーロッパでは旅に疲れた人々のためにカ トリック修道会が設けた無料宿泊所をホスピスと呼 び，しだいに病人，負困者たちを世話するところをホ スピスと呼ぶようになった。そして，19世紀のアイル ランドのダブリン修道女会の創立者 Mary Aikenheadによって，末期患者のケアを専門にする施設が 今日のホスピスの始まりであるといわれている。 ${ }^{344)}$ 現 在ではイギリス，アメリカ，オーストラリアなどに広 まり，イギリスのマリー・キュリ一財団をはじめ，施 設の多くは慈善団体により運営されている。現在のホ スピスは各種の宗教と密接な関係をもっている。今世 紀初頭には結核患者のケアであったが, 現在ではおも に末期癌患者を対象にしたケアが行なわれている。5 ホスピス医療の特徵は，末期患者の 4 つの痛みを緩和 することである。(1) Physical pain, 身体的痛み特に末 期癌患者などの場合, モルヒネ，コカイン等を投与し 疼痛を緩和する。(2) Mental pain, 不安, 恐れ, 孤独 などの精神的痛みに対しての心のささえをする。(3) Social pain，病気になったために起こる経済的，家庭 的問題や人間関係など社会的痛みに対しての助言をす る。(4) Spiritual pain, 死や死後の世界をどう考之るか など信仰的痛みに対しての援助をする。などがホスピ 又医療の基盤である。我国でも現在, 淀川キリスト教 病院, 聖隷三方原病院などが存在する。6)

\section{NLM Literature Search と調查方法}

NLM Literature Searchは主にMEDLINEを用
い，テーマによっては他のデータベースも併用して文 献検索をしたなかから，広く興味深いテーマを選んで, リプリントしたものである。1980〜1984年の 5 ヶ年間 を調查してみると，年間 30 冊 $(30$ テーマ $)$ 程が刊行さ れ，収載文献は最近 3 ヶ月前のものから過去 10 年前の 文献に分布し, 収載期間は平均 4 年 6 ヶ月であった。 162 冊（146テーマ）が刊行され, 合計 38,816 文献が掲 載されている。そのなかで特に注目されるテーマとし ては, Acquired Immunodeficiency Syndrome(AIDS) が 6 冊, 2,177文献が揭載されていた。ホスピスはNo. 84-4の 1 件で421文献が掲載されている。162冊の テーマをNLMC を用いて分類してみると，34主題分 野に分類され，その結果から医学全般から広くテーマ を選択していることが判る。最も多かった主題分野は, 薬理学関係で25冊を占めていた。刊行されていなかっ た主題分野は, 人体解剖学, 寄生虫学, 臨床病理学, 眼科学, 医学史の 5 主題分野のみであった。作成者(検 索者）は22名が抽出され，NLMの Charlotte Kenton が78冊を作成し最も多く，テーマによってはその分野 の専門家が作成を行なっていた。

今回の調查対象文献は, NLM Literature Search No. $78-8$ の92文献と No. $84-4$ の 421 文献合計523 のホスピス文献である。No. 79-8は Patricia E. Healy が主に MEDLINE を用い作成にあたり，収載 文献は1966年 1 月から 1979年 5 月までの文献である。 No. 84-4は, Library of the American Hospital Associationの Susan Bolda Marshall がデータベー スの HEALTH PLANNING AND ADMINISTRATION，BIOETHICS，AVLINE を用い作成にあたり， 収載文献は1979年 6 月から 1984 年 2 月までの文献であ る。No.84-4 では, Editorials, News, Letters, Interviewsは除外してあり，そして英文のみの文献である。

調查方法は上記のホスピス文献をコピーし， 1 件ご と八サミで切断し，標準図書カードに貼り基礎カード を作成した。Ulrich's International Periodicals Directory (以下 Ulrich's) を参考資料とし, 基礎カードに雑 誌の主題分類 DDC No., 発行国を追記し基本カードと した。そしてホスピス文献の雑誌調查(1)雑誌ランキン グ(2)発行国分布(3)主題別分布(4)年代推移と，木スピス 
文献に付与されていた Descriptor 調查(1) Major Descriptor ランキング(2) 1 文献当たりの Major Descriptor 数と All Descriptor 数の分布 (3) Descriptor の年 代推移(4) Descriptor $\ulcorner$ Hospices」の Subheading 数の 推移について，各調査項目ごとに配列し集計した。

\section{IV. 調查結果}

\section{1. ホスピス文献雑誌調査結果}

\section{1）雑誌ランキング}

ホスピス文献523件について雑誌ランキングを表 1 に示す。表 1 は左から順位, 雑誌名, 発行国, 主題, 件数，件数の百分比の順で表示してある。53位は 2 件 で同順位のものが43誌あったことを意味する。1 位は 誌名 Caring で発行国はアメリカ, 主題は Nursing で 22件 (4.21\%) である。2 位は同様に Nurs Times一イ ギリスーNursing と HospitalsーアメリカーHospitals が共に15件 (2.87\%) であった。合計238誌が抽出 され，その結果から特定雑誌への木スピス関連文献の 集中が見られず，多くの雑誌へと分散していることが 判る。

\section{2）発行国分布}

ホスピス文献523件について発行国分布を図 1 に示 す。図 1 は件数についで印を 10 件*印を 1 件と表し
ている。抽出された 238 誌は 17 ヶ国から発行され，1位 アメリカ 162 誌 361 件 $(69.03 \%) ， 2$ 位イギリス 24 誌 77 件 (14.72\%)，3 位カナダ11誌19件（3.63\%）と続き， 本国発行誌は 10 位 3 誌 3 件（0.58\%）であった。図 1 からホスピス文献は特にアメリカ，イギリスに集中し て発行されていることが判る。

\section{3）主題別分布}

抽出された 238 誌について，その主題別分布をUlrich's を用い分類し表 2 に示す。表 2 は, 主題, 雑誌数, 件数, 件数の百分比, 件数／雑誌数の順で示してある。 全体で32主題に分類され，うち不明12誌16件であった。 1 位は主題が Medical Science-Nurses and Nursing で57誌147件 (28.11\%)であった。以下同様に Medical Science 73 誌145件 (27.73\%)， 3 位 Hospitals 27 誌 91 件 (17.41\%) と続く。上位 3 主題の合計は, 雑誌数に おいて157誌(65.97\%)，件数において383件 (73.25\%) と多くを占めていた。そして, Psychology, Public Health and Safety, Pharmacy and Pharmacology, Gerontology and Geriatrics が10件以上の上位にあげ られた。

表 2 のデータをもとに主題別分布図を図 2 に示す。 図 2 は縦軸に件数を横軸にDDC No.を表示してある。 困 2 から616,617番台の医学系が多くを占め, 次に 300 番台の病院, 社会福祉, そして150番台の心理学などが

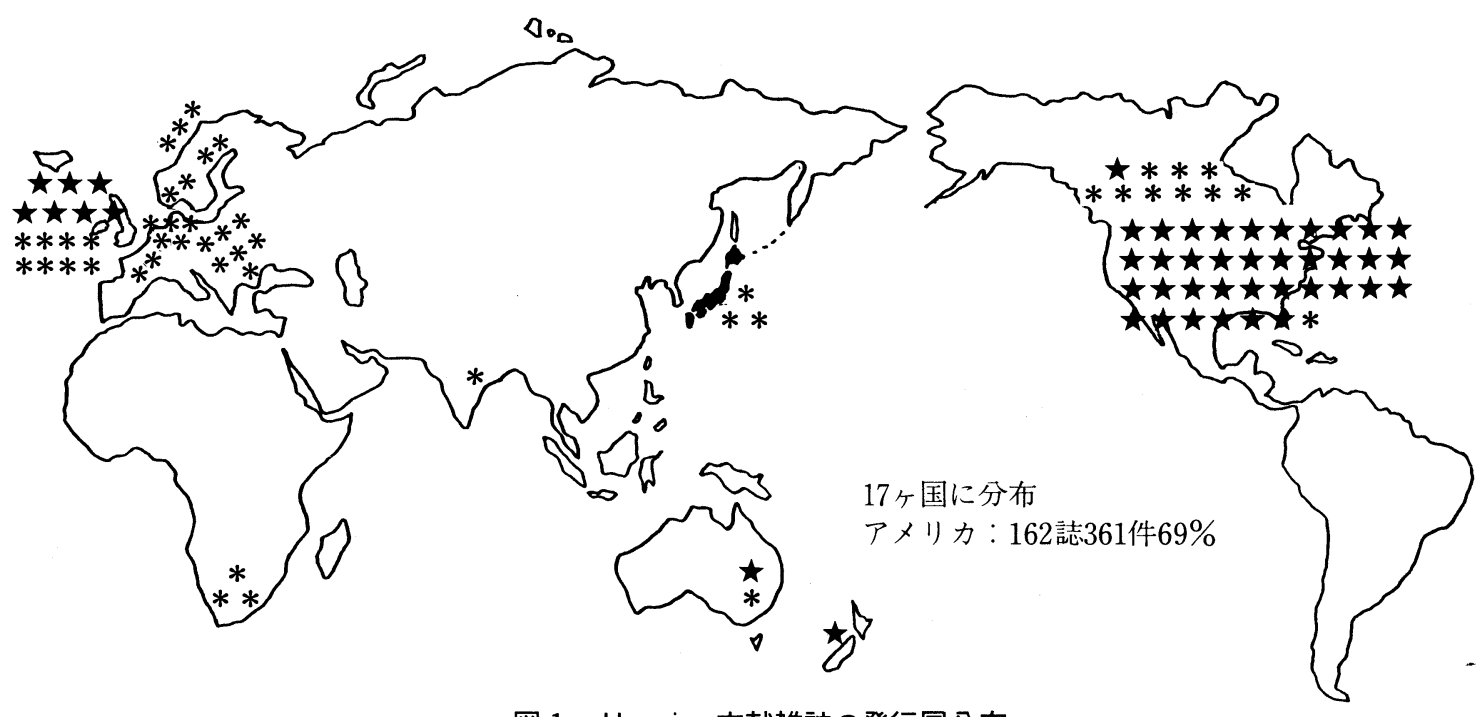

図 1. Hospice 文献雑誌の発行国分布 
表 1. Hospice 文献の雑誌ランキング

\begin{tabular}{|c|c|c|c|c|c|}
\hline 順位 & 誌 & 発行国 & 題 & 件 数 & $\%$ \\
\hline 1. & Caring & U.S.A. & Nursing & 22 & 4.21 \\
\hline 2. & Nurs. Times & U.K. & Nursing & 15 & 2.87 \\
\hline 2. & Hospitals & U.S.A. & Hospitals & 15 & 2.87 \\
\hline 4. & Hosp. Prog. & U.S.A. & Hospitals & 13 & 2.49 \\
\hline 5. & Nurs. Mirror & U.K. & Nursing & 11 & 2.10 \\
\hline 6. & Death Educ. & U.S.A. & Psychology & 9 & 1.72 \\
\hline 7. & Am. J. Nurs. & U.S.A. & Nursing & 8 & 1.53 \\
\hline 8. & Am. Pharm. & U.S.A. & Pharmacy & 7 & 1.34 \\
\hline 8. & Am. Psychol. & U.S.A. & Psychology & 7 & 1.34 \\
\hline 8. & Br. Med. J. & U.K. & MS* & 7 & 1.34 \\
\hline 8. & Nurs. Outlook & U.S.A. & Nursing & 7 & 1.34 \\
\hline 8. & Q.R.B. & U.S.A. & Hospitals & 7 & 1.34 \\
\hline 13. & Aust. Nurses J. & Australia & Nursing & 6 & 1.15 \\
\hline 13. & Cancer Nurs. & U.S.A. & Nursing & 6 & 1.15 \\
\hline 13. & Fam. Community Health & U.S.A. & Public Health & 6 & 1.15 \\
\hline 13. & Hosp. Forum & U.S.A. & Hospitals & 6 & 1.15 \\
\hline 13. & Hosp. Med. Staff & U.S.A. & Hospitals & 6 & 1.15 \\
\hline 13. & J.R. Coll. Gen. Pract. & U.K. & MS & 6 & 1.15 \\
\hline 13. & Lancet & U.K. & MS & 6 & 1.15 \\
\hline 13. & NZ. Nurs. J. & New Zealand & Nursing & 6 & 1.15 \\
\hline 21. & Bull. Am. Protestant Hosp. Assoc. & U.S.A. & Hospitals & 5 & 0.96 \\
\hline 21. & Can. Med. Assoc. J. & Canada & MS & 5 & 0.96 \\
\hline 21. & Minn. Med. & U.S.A. & MS & 5 & 0.96 \\
\hline 21. & Nursing & U.S.A. & Nursing & 5 & 0.96 \\
\hline 21. & Oncol. Nurs. Forum & U.S.A. & Nursing & 5 & 0.96 \\
\hline 26. & Bull. Am. Coll. Surg. & U.S.A. & Surgery & 4 & 0.76 \\
\hline 26. & Contemp. Adm. & U.S.A. & Hospitals & 4 & 0.76 \\
\hline 26. & J. Am. Geriatr. Soc. & U.S.A. & Geriatrics & 4 & 0.76 \\
\hline 26. & J. Fam. Pract. & U.S.A. & MS & 4 & 0.76 \\
\hline 26. & J. Long Term Care Adm. & U.S.A. & Hospitals & 4 & 0.76 \\
\hline 26. & Long Term Care Health Serv. Adm. Q. & U.S.A. & Public Health & 4 & 0.76 \\
\hline 26. & Mich. Med. & U.S.A. & MS & 4 & 0.76 \\
\hline 26. & NZ. Med. J. & New Zealand & MS & 4 & 0.76 \\
\hline 26. & NY. State J. Med. & U.S.A. & MS & 4 & 0.76 \\
\hline 26. & Prog. Clin. Biol. Res. & U.S.A. & MS & 4 & 0.76 \\
\hline 26. & Practitioner & U.K. & MS & 4 & 0.76 \\
\hline 37. & Am. Nurse & U.S.A. & Nursing & 3 & 0.57 \\
\hline 37. & Bus. Insur. & U.S.A. & Insurance & 3 & 0.57 \\
\hline 37. & Conn. Med. & U.S.A. & MS & 3 & 0.57 \\
\hline 37. & Employ. Benefit Plan Rev. & U.S.A. & Business and Economics & 3 & 0.57 \\
\hline 37. & Hastings Cent. Rep. & U.S.A. & Biology & 3 & 0.57 \\
\hline 37. & Health Soc. Serv. J. & U.K. & Hospitals & 3 & 0.57 \\
\hline 37. & Health Soc. Work & U.S.A. & Social Services & 3 & 0.57 \\
\hline 37. & Home Health Care Serv. Q. & U.S.A. & Hospitals & 3 & 0.57 \\
\hline 37. & J. Gerontol. Nurs. & U.S.A. & Gerontology & 3 & 0.57 \\
\hline 37. & J. Med. Ethics & U.K. & MS & 3 & 0.57 \\
\hline 37. & Med. Care & U.S.A. & MS & 3 & 0.57 \\
\hline 37. & Mod. Health Care & U.S.A. & Hospitals & 3 & 0.57 \\
\hline 37. & N. Engl. J. Med. & U.K. & MS & 3 & 0.57 \\
\hline 37. & Postgrad. Med. J. & U.K. & MS & 3 & 0.57 \\
\hline 37. & Sykepleien & Norway & Nursing & 3 & 0.57 \\
\hline 37. & Tex. Hosp. & U.S.A. & Hospitals & 3 & 0.57 \\
\hline 53. & AMHC Forum & & & $2(43)$ & 16.44 \\
\hline \multirow[t]{3}{*}{96.} & AARN News Lett. & & & $1(143)$ & 27.34 \\
\hline & Book & & & 1 & 0.19 \\
\hline & Total & & & 523 & 100.00 \\
\hline
\end{tabular}


目立っている。

\section{4）年代推移}

ホスピス文献の年代推移を図 3 に示す。困 3 は年度 別の総件数と，表 2 の主題別分布で多くを占めていた
上位 3 主題 (Medical Science-Nurses and Nursing, Medical Science, Hospitals) とその 3 主題以外をその 他とする 4 項目に分け，縦軸に件数を横軸に発行年を それぞれ折れ線グラフで示してある。図 3 から総件数,

表 2. Hospice 文献の主題別分布

\begin{tabular}{|c|c|c|c|c|}
\hline $\begin{array}{l}\text { Ulrich's Classified List of } \\
\text { Periodicals/Subjects }\end{array}$ & $\begin{array}{l}\text { 雑誌数 } \\
\quad(1)\end{array}$ & $\begin{array}{c}\text { 件数 } \\
(2)\end{array}$ & $\%$ & $(2) /(1)$ \\
\hline MS-Nurses and Nursing & 57 & 147 & 28.11 & 2.58 \\
\hline MS & 73 & 145 & 27.73 & 1.97 \\
\hline Hospitals & 27 & 91 & 17.41 & 3.37 \\
\hline Psychology & 3 & 18 & 3.44 & 6.00 \\
\hline Public Health and Safety & 9 & 18 & 3.44 & 2.00 \\
\hline Pharmacy and Pharmacology & 6 & 13 & 2.49 & 2.17 \\
\hline Gerontology and Geriatrics & 6 & 12 & 2.29 & 2.00 \\
\hline Social Services and Welfare & 6 & 9 & 1.72 & 1.50 \\
\hline MS-Surgery & 4 & 7 & 1.34 & 1.75 \\
\hline MS-Cancer & 4 & 6 & 1.15 & 1.50 \\
\hline MS-Pediatrics & 4 & 5 & 0.96 & 1.25 \\
\hline MS-Psychiatry and Neurology & 4 & 4 & 0.77 & 1.00 \\
\hline Insurance & 2 & 4 & 0.77 & 2.00 \\
\hline Biology & 1 & 3 & 0.57 & 3.00 \\
\hline $\begin{array}{l}\text { Business and Economics - } \\
\text { Labor Industrial Relations }\end{array}$ & 1 & 3 & 0.57 & 3.00 \\
\hline Law & 2 & 3 & 0.57 & 1.50 \\
\hline Political Science & 3 & 3 & 0.57 & 1.00 \\
\hline MS-Forensic Sciences & 1 & 2 & 0.38 & 2.00 \\
\hline MS-Otorhinolaryngology & 1 & 2 & 0.38 & 2.00 \\
\hline MS-Radiology and Nuclear Medicine & 2 & 2 & 0.38 & 1.00 \\
\hline Physical Fitness and Hygiene & 2 & 2 & 0.38 & 1.00 \\
\hline MS-Dentistry & 1 & 1 & 0.19 & 1.00 \\
\hline Food and Food Industries & 1 & 1 & 0.19 & 1.00 \\
\hline $\begin{array}{l}\text { General Interest Periodicals - } \\
\text { United States }\end{array}$ & 1 & 1 & 0.19 & 1.00 \\
\hline Nutrition and Dietetics & 1 & 1 & 0.19 & 1.00 \\
\hline Management of Public Households & 1 & 1 & 0.19 & 1.00 \\
\hline Religions and Theology & 1 & 1 & 0.19 & 1.00 \\
\hline $\begin{array}{l}\text { Public Administration - } \\
\text { Municipal Government }\end{array}$ & 1 & 1 & 0.19 & 1.00 \\
\hline Science: Comprehensive Works & 1 & 1 & 0.19 & 1.00 \\
\hline 不 明 & 12 & 16 & 3.06 & 1.25 \\
\hline Total & 238 & 523 & $\begin{array}{r}100.00 \\
\text { MS: Medi }\end{array}$ & ience 略 \\
\hline
\end{tabular}



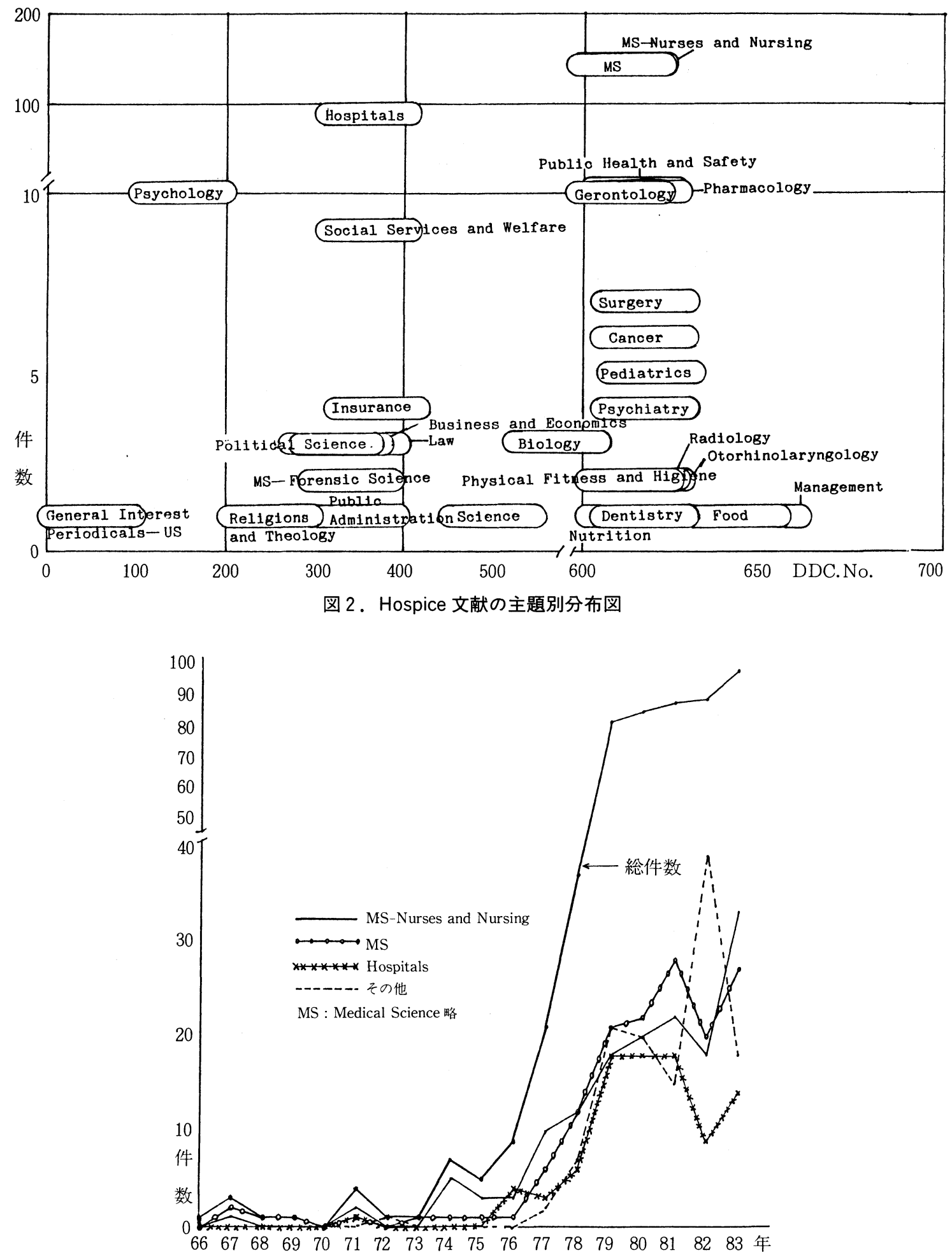

図 3. Hospice 文献の年代推移 
4 項目とも1976年から1979年にかけて急増し，その後 も漸增傾向にあることが明確である。

2. ホスピス文献に付与されていた Descriptor 調查 結果

1) Major Descriptor ランキング

ホスピス文献523件について，どのような Major Descriptor が付与されているか, そのランキングを表 3 に示す。表 3 は, 順位, Major Descriptor 名, 個数, 523件中に占める各個数の百分比の順で表示してある。 20位は Mojor Descriptor 数は 5 個で, 同順位のものが 7 種類あったことを意味する。全体で189種類の Major Descriptor が抽出され，合計1,304個であった。 1
位の Major Descriptor は Hospices であり，523件中 395個（75.53\%）に付与されていた。2 位 Terminal Care 250個 (47.78\%)，3 位 Hospitals, Special98個 （18.74\%）と続き，上位 3 種類の Major Descriptor の合計個数は 743 個で1,304個中の $(56.98 \%)$ を占めて いた。以下，20個以上の Major Descriptor は，Home Care Services, Neoplasms, Attitude to Death, Palliative Treatment, Health Insurance for Aged and Disabled, Title 18 と続く。

2） 1 文献当たりの Major Descriptor 数と All

\section{Descriptor 数分布}

1 文献について何個の Descriptor が付与されてい

表 3. Major Descriptor ランキング

\begin{tabular}{|c|c|c|c|}
\hline 順位 & Major Descriptor & 個数 & 個数 $/ 523 \times 100$ \\
\hline 1. & Hospices & 395 & 75.53 \\
\hline 2. & Terminal Care & 250 & 47.78 \\
\hline 3. & Hospitals, Special & 98 & 18.74 \\
\hline 4. & Home Care Services & 63 & 12.05 \\
\hline 5. & Neoplasms & 39 & 7.46 \\
\hline 6. & Attitude to Death & 29 & 5.54 \\
\hline 7. & Palliative Treatment & 23 & 4.40 \\
\hline 8. & $\begin{array}{l}\text { Health Insurance for Aged } \\
\text { and Disabled, Title } 18\end{array}$ & 22 & 4.21 \\
\hline 9. & Patient Care Team & 13 & 2.49 \\
\hline 9. & Nursing Care & 13 & 2.49 \\
\hline 11. & Ethics, Medical & 9 & 1.72 \\
\hline 12. & Hospital Units & 8 & 1.53 \\
\hline 13. & Health Services Research & 7 & 1.34 \\
\hline 13. & Hospital Planning & 7 & 1.34 \\
\hline 13. & Nursing Staff & 7 & 1.34 \\
\hline 13. & Stress, Psychological & 7 & 1.34 \\
\hline 17. & Family & 6 & 1.15 \\
\hline 17. & Insurance, Health & 6 & 1.15 \\
\hline 17. & Voluntary Workers & 6 & 1.15 \\
\hline 20. & & $5(7)$ & \\
\hline 27. & & $4(10)$ & \\
\hline 37. & & $3(15)$ & \\
\hline 52. & & $2(38)$ & \\
\hline \multirow[t]{2}{*}{90.} & & $1(100)$ & \\
\hline & Total & 1304 & \\
\hline
\end{tabular}


るか図 4 に示す。図 4 は縦軸に件数, 横軸に Descriptor 数を Major Descriptor を実線で, All Descriptor を点線の折線グラフで示してある。図 4 から Major Descriptor 数では 1 個84件， 2 個205件， 3 個 144 件, 4 個 78 件， 5 個 11 件， 6 個 2 件で， 2 個付与されてい たものが最も多く523件中（39.20\%）を占めていた。 次に, All Descriptor 数の分布では 2 個11件から漸増

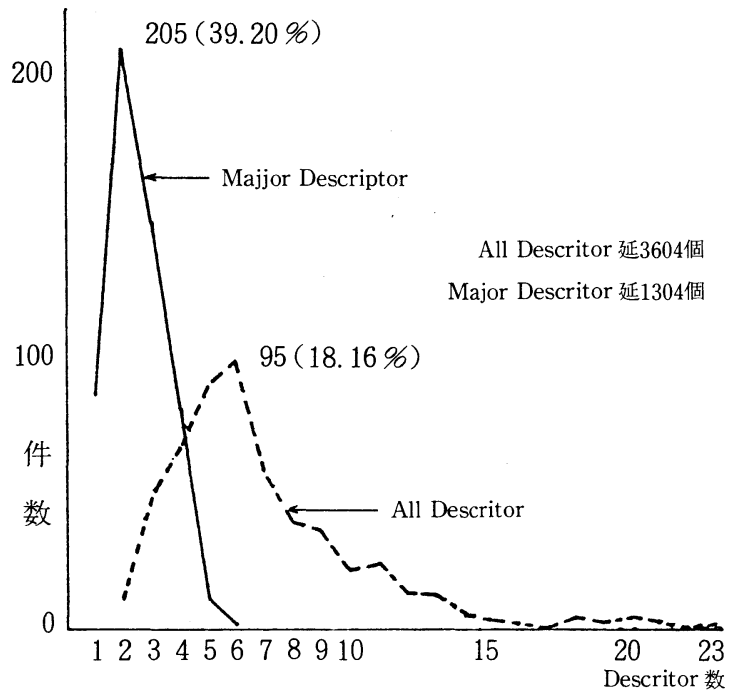

図 4.1 文献当たクの Major Descriptor 数と All Descriptor 数分布
し，6 個95件 (18.16\%) が最も多く，なかには23個も 付与されていたものが 1 件あった。延べ数は 3,604 個で あった。

\section{3) Descriptor $の$ 年代推移}

表 3 の Major Descriptor ランキングで上位 3 種類 の Descriptor (Hospices, Terminal Care, Hospitals, Special）について，ホスピス文献が著しい増加を示し た1976年から1983年までの 8 年間を対象にして，どの ように変化したかを図 5 に示す。図 5 は，縦軸に各年 度に発行されたホスピス文献の総件数に対しての百分 比を，横軸に発行年を折線グラフで示してある。図 5 から Terminal Care, Hospitals, Special は減少し，そ のかわりにHospices が多く付与され始めてきたこと が判る。

4) Descriptor $\ulcorner$ Hospices」の Subheading 数の推移 最後にDescriptor「Hospices」にどのような Subheading が付与されているか表 4 に示す。表 4 は1976 年から1983年までの 8 年間を対象にし, Subheading について件数の多い順に上から表示してある。Hospices（N2. 278. 421.556.210）は Classification, Economics, Education, History, Legislation \& jurisprudence, Manpower, Methods, Organization \& administration, Standards, Supply \& distribution, Tren-

表 4. Descript or "Hospices" の Subheading 数の推移

\begin{tabular}{|c|c|c|c|c|c|c|c|c|c|}
\hline Subheading の種類 & 76 & 77 & 78 & 79 & 80 & 81 & 82 & 83 & Total \\
\hline Organization \& Administration & & & 6 & 31 & 24 & 24 & 21 & 18 & 124 \\
\hline Economics & & & 4 & 7 & 2 & 7 & 15 & 18 & 53 \\
\hline Trends & & & 1 & 7 & 11 & 2 & 3 & 4 & 28 \\
\hline Standards & & & 1 & 2 & 3 & 2 & 9 & 10 & 27 \\
\hline Legislation \& Jurisprudence & & & & 1 & 2 & & 5 & 8 & 16 \\
\hline Manpower & & & & 4 & 2 & & 1 & 1 & 8 \\
\hline Utilization & & & & 1 & 1 & 1 & 3 & & 6 \\
\hline Supply \& Distribution & & 1 & & 1 & & 2 & & & 4 \\
\hline History & & & & 2 & & & 1 & & 3 \\
\hline Total & & 1 & 12 & 56 & 45 & 38 & 58 & 59 & 269 \\
\hline なし & 1 & 15 & 29 & 27 & 26 & 37 & 23 & 33 & 191 \\
\hline Grand Total & 1 & 16 & 41 & 83 & 71 & 75 & 81 & 92 & 460 \\
\hline
\end{tabular}




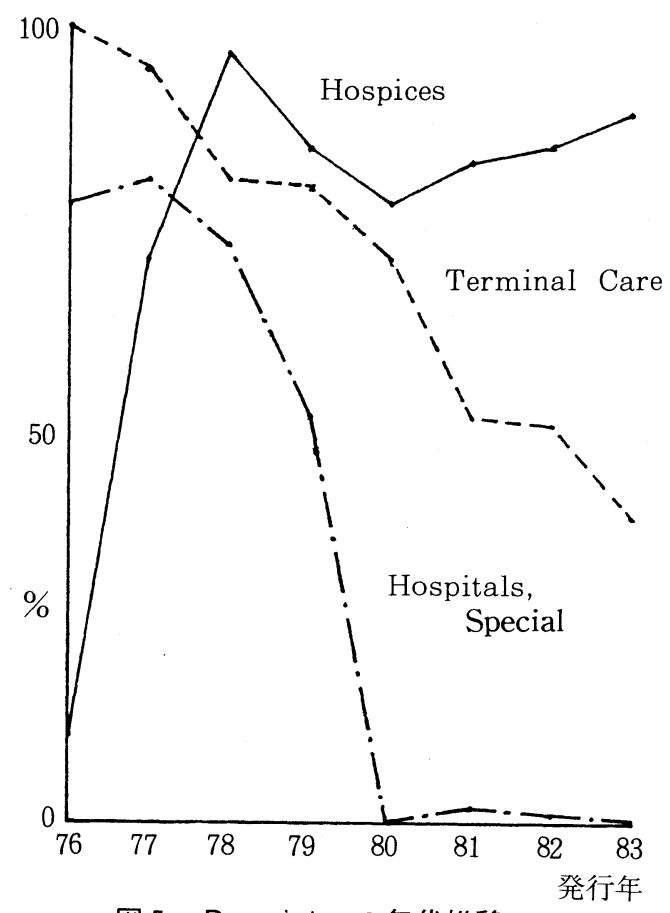

図 5.Descriptor の年代推移

ds, Utilization 以上12種類の Subheading と伴って keywordとして用いることができる。今回の調査では 9 種類の Subheading が抽出され, Organization \& administration が124件と最も多くを占めていた。以 下 Economics53件, Trends28件, Standards27件, Legislation \& jurisprudence16件と続く。なかには Subheading が 2,3 種類重複して付与されている文 献もあった。Subheading が付与されている Descriptor $\ulcorner$ Hospices」は1979年に急增し, その後大きな変化 は認めない。Subheading が付与されていない Descriptor「Hospices」は1977年から1978年を境に増加して いることが判った。

\section{V. 考 察}

雑誌ランキングではホスピス文献523件に対し, 238 誌が抽出され, 特定の Core Journal は存在せず「ブ ラッドフォードの分散則」7ににみれるような曲線は 認められなかった。NLM Literature Search No.844 はデータベースを主にHEALTH PLANNING
AND ADMINISTRATIONを用いたため， 1 位の Caring を始め上位20誌中 I. M.（1985年版）未収載誌 が11誌も占めている。このデータベースは衛生管理の 実施に関する非臨床的側面を扱う文献を収録してお $\eta$, Hospital Literature Index がベースのため, I. M. 未収載誌が多数含まれたと考之られる。発行国分布に 扔いては，アメリカとホスピス発祥の地であるイギリ スの雑誌が多くを占めている。国内雑誌は NLM Literature Search No.79-8に収載されていた, Craven J, Wald FS 著：看護研究10（ 5 ）：398-405，1977., 柏 木哲夫著：日本臨床 Suppl. 1792-1973，1978.，季羽 倭文子著：看護展望 $3(6)$ ：12-17．1978。 の 3 誌の みであった。主題別分布は看護学はもとより医学一般, 病院学, 心理学, 社会福祉, 薬理学, 老年学などが, 当然のことながら雑誌数, 件数共に多くを占めている。 しかし，34主題と広い主題分野の雑誌に分散していた ことは予想外の結果であった。この結果からホスピス は, 広範囲な学問領域から研究対象になっていること が判る。Barbara Greenall ${ }^{2)}$ は，ホスピス文献収載雑 誌を 5 項目 (Medical journals, Nursing journals, Health care journals, Other subject journals, Newspapers）に分け，イギリス，アメリカ両国の比較を試 みている。この結果イギリスでは Nursing journal が, アメリカでは Health care journal がそれぞれ高値を 示し，両国間においてホスピス文献収載雑誌に相違が あるという興味ある報告をしている。年代推移におい ては1977年を境に文献数の急激な増加がみられた。 MeSH Term として Hospices が Hospitals, Special から分離し，1977年 8 月から採用されておりこの状況 と一致する。しかし1979年以降著しい増加はみられて いない。1 文献当たりの Major Descriptor 数とAll Descriptor 数分布においては, Major Descriptor では 2 個, All Descriptor では 6 個がそれぞれ最も多くを 占めていた。 1 文献当たりの索引語の数は平均12個の DescriptorにCheck Tag を加えたもので, 最高25個 まで付与する。この中の Major Descriptor は 2 または 3 個とする。但し, 1981年以降は Descriptorの数を平 均 $8-10$ 個に減少させている。」という小松の報告8) と 同様な結果が得られた。Descriptor「Hospices」の推 
移においては, Subheading を伴わないHospices が増 加した年度より，1〜2年後から Subheading を伴っ たDescriptor $「$ Hospices」の急増が認められた。今後, New MeSH Term と Subheading の付与率の関係に ついて興味の持たれるところである。Subheadingの 種類は, 組織と管理, 経済, 基準, 法制と法学, 利用 などが増加していた。この結果から，次第にホスピス 活動が具体化し，現実的に展開されつつあることが伺 われる。

\section{VI. 要 約}

今回, NLM Literature Search No.79-8, No.844 双方に揭載されていたホスピス文献523件を対象に して，定量的調査を行ない次のような結論を得た。

(1)雑誌ランキングは523文献中 238 誌が抽出された。 1 位は Caring で22件 $(4.21 \%)$ と低值であり，ホスピ ス文献中にはCore Journal は認められなかった。

(2)発行国分布は 238 誌が17 ケ国から発行され，1位は アメリカで162誌361件（69.03\%）と抜きん出ていた。 2 位はホスピス発祥の地イギリスで 24 誌 77 件 （14.72\%）であり，両国発行誌が多くを占めていた。 (3)主題別分布は238誌を NLMC を用いると，32主題 分野に分類された。1位の主題分野は, Medical Science-Nurses and Nursing で57誌147件（28.11\%）で あり, 以下 Medical Science, Hospitals が多くを占め ていた。そして，DDC 番号616，617番台の医学系の雑 誌が多くを占め, 次に 300 番台の病院, 社会福祉, 150 番台の心理学などが際立っている。

(4)ホスピス文献の推移は，1976年から1979年にかけ て急增し，その後も漸増傾向にある。

(5) Major Descriptor ランキングは189種類の Major Descriptor が抽出され，1 位はHospicesであり 523件中395個（75.53\%）に付与されていた。

(6) 1 文献当たりの Major Descriptor 数と All Descriptor 数分布は, Major Descriptor 数の付与率は, 2 個205件が最も多くを占めていた。All Descriptor 数の 付与率は， 6 個95件が最も多くを占めていた。

(7)1976年から1983年の Descriptor の年代推移は,
Terminal care, Hospitals, Special に変わって Hospicesが増加していた。

(8) Descriptor「Hospices」に付与されていたSubheading 数の推移においては，9種類の Subheading が抽出された。Organization \& administration が124 件と抜きん出ていた。以下 Economics, Trends, Standards, Legislation \& jurisprudence が多くを占めて いた。Subheading を伴わない Descriptor $\ulcorner$ Hospices」 が増加した年度より，1～2 年後から Subheadingを 伴った Descriptor「Hospices」の急増が認められた。

\section{VII. おわりに}

我国でも急速な高齢化社会が進むなかで，ホスピス の存在は今後注目されていくことだろう。敗戦直後国 民の $90 \%$ 以が自宅死であったが，今日では死をむか える場所として病院 $58.6 \%$, 診療所 $4.5 \%$, 自宅 $32.1 \%$, その他 $4.8 \%$ であり，すでに自宅死が 3 分の 1 以下に 減っている。 ${ }^{9)}$ 大都市周辺では70\%以上が病院で死を むかえている。医療者側の関心はもっぱらCure(治療) におかれ，死を前にした末期患者の Care (看護)につ いては，医療の本質的対象ではないとする考之方が中 心を占めていた。しかし，質や価值が国民の関心とな クつつある現在，これらのニーズに答える援助が末期 医療「やすらかな死」へのあり方として今後重要視さ れるだろう。しかし, 我国では現在, プロテスタント 系病院の付属病棟型の 2 病院が存在するのみである。 将来宗教的基盤が薄い日本で，ホスピス活動がどのよ うに展開されていくものか注目される。

本稿は今年 6 月 1 日, 2 日の両日, 大阪歯科大学で 開催された，第 2 回図書館情報サービス研究大会にお いての発表に加筆したものである。最後に本稿を終る にあたり，ご指導ご助言をいただいた当館の兼岩健二 氏に深く感謝いたします。

\section{参 考 文 献}

1） Kenneth P. Cohen 著 斉藤武, 柏木哲夫訳：木ス ピス一末期医療の思想と方法一東京, 医学書院, 
1982.

2) Barbara Greenall : Development of the United Kingdom Hospice Movement, 1976-1981. Occasional Publication. No. 6, 1982.

3）原義雄, 千原明：ホスピス・ケア一看取りの医療 への提言一, 東京, メディカルフレンド社, 1983.

4） Stoddard, S. 著 高見安規子訳：ホスピス・ムー ヴメント〜よりよき生のために〜，東京，時事通 信社, 1982 .

5）沖藤典子：平安なれ命の終りーホスピス病棟から の報告一, 東京, 新潮社, 1982 .
6）池見西次郎，永田勝太郎：日本のターミナル・ケ ア，末期医療学の実践，東京，誠信書房， 1984.

7) Bradford, S. C. : Documentation. London, Lookwood \& Son, 1953. p. 144-159.

8）小松三蔵：Index Medicusの索引とDIALOG の MEDLINE での利用, 医学図書館, 30 ( 1 )：36$46,1983$.

9）厚生省大臣官房統計情報部編：人口動態統計。中 巻, 第 8 表. 死亡数性死亡の場所, 東京, 厚生統 計協会, 1985 .

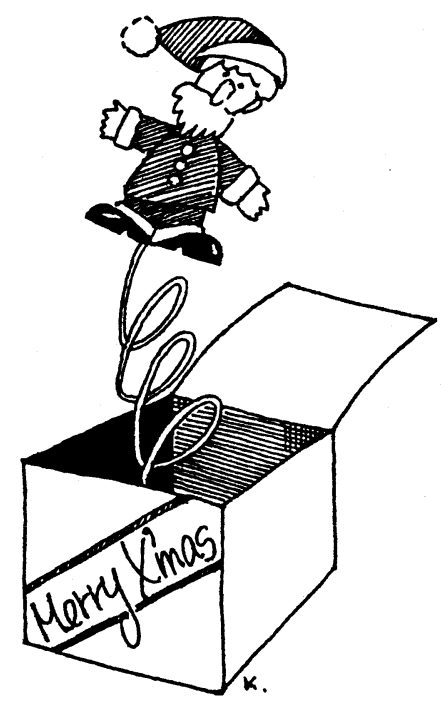

